\title{
IDENTIFIKASI KEBUTUHAN KOMPETENSI SUMBER DAYA MANUSIA INDUSTRI PERHOTELAN KABUPATEN BANTUL
}

\author{
Prihatno \\ NIDN : 0526125901 \\ prihatno_prihatno@yahoo.com \\ Dosen Sekolah Tinggi Pariwisata AMPTA Yogyakarta
}

\begin{abstract}
ABSTARCT
At present the accommodation services business has become a service industry and is a labor-intensive business means Human Resources support becomes the mainstay of business success. Improved customer service requires a more professional Human Resource capability.

As a standard measure that professionals in the field of tourism including hospitality staff and restaurants is possessed a certificate of competence recognized by the National Agency for Professional Certification.

In Bantul Regency this accommodation business is growing very rapidly following the development of tourism. The number of existing hotels and inns has reached 95 units for the class with the number of medium rooms, but if recorded all including lodging in the location of objects that only has one room, the number reaches 261 pieces and may continue to grow in the future With the emergence of objects of new attractions.

Bantul regency government tries to formulate its development strategy by conducting study of identification of human resource competency requirement for hotel industry in order to give space for the growth and development of hospitality industry in Bantul regency in the future.

This study was conducted by taking 30 samples from the workforce and the guest response from the type of accommodation in the form of hotels totaling 5 pieces, the only business mentioning the lodgings amounted to 8 pieces, inn 9 pieces, cabin 6 pieces and each 1 fruit is Inn and Guest House. The data collected by questionnaire and documentation is then processed using Spencer \& spencer competency analysis, especially non technical competency or soft competency to determine the level of incompetent to very competent while also ranking the competency level required in the hotel industry.

From the research results obtained data real needs of hotel industry competence which then rearranged and selected based on priority scale likert between 1-4. By using competency guideline in Indonesia from work competency standard especially hotel and restaurant area mapped to get requirement of human resource competence for Hotel Industry in Bantul Regency.
\end{abstract}

Keyword: Soft Competency, Hard Competency dan Kompetensi SDM Hotel

\section{PENDAHULUAN}

Dengan adanya tuntutan liberalisasi pasar global dalam lingkup internasional, regional dan sub-regional serta adanya kesepakatan terbukanya mobilitas tenaga kerja professional di berbagai bidang termasuk dibidang pariwisata, dimana tenaga professional tersebut dituntut untuk memiliki kompetensi kerja yang dapat dibuktikan melalui sertifikat kompetensi yang valid dan diakui. Salah satu unsur dari bidang pariwisata yang keberadaannya sangat penting adalah sarana akomodasi.

Hotel termasuk usaha akomodasi. Selain hotel maka Usaha akomodasi juga bisa dibedakan berdasarkan jenis aktivitasnya yaitu seperti Motel, Losmen atau penginapan (Lodgements), Pondok Remaja ( Youth hostels), Bumi Perkemahan (Camping ground), Pondok Wisata atau Wisma ( homestay atau Gusent House), Marina, Jenis jenis akomodasi lain seperti Pondok (Inn).

Usaha jasa Akomodasi pada saat ini sudah menjadi industri jasa dan merupakan usaha padat karya artinya dukungan Sumber Daya Manusia menjadi andalan kesuksesan bisnisnya. Upaya untuk meningkatkan kemampuan sumber daya manusia menjadi lebih profesional sudah menjadi kebutuhan peningkatan pelayanan pelanggan.

Sebagai standar ukuran bahwa tenaga profesional dibidang pariwisata termasuk di dalamnya adalah tenaga perhotelan dan restoran adalah dimilikinya sertifikat kompetensi yang diakui oleh Badan Nasional Sertifikasi Profesi.

Asisten Deputi Pengembangan SDM Kemenpar Wisnu Bawa Tarunajaya pada Senin 15 Februari 2016 mengungkapkan bahwa sampai dengan tahun 2015 telah lulus uji kompetensi bidang pariwisata sebanyak 121.000 orang dari 320,000 total SDM Pariwisata berdasar data resmi Kemenpar yang ditargetkan bisa mencapai $100 \%$ sertifikasi profesi pada 2019 , terutama untuk SDM perhotelan dan restoran yang telah disepakati untuk free flow.

Pemerintah Kabupaten Bantul telah membaca isyarat target pemerintah pusat tersebut untuk menyiapkan tenaga pariwisata terutama bidang hotel dan restoran di tahun 2019 sebanyak 100\%, tentu 
memerlukan dukungan dari semua pemerintah daerahnya, karena SDM pariwisata terutama hotel dan restoran sebagai targetnya berada tersebar di semua wilayah di Indonesia termasuk di Kabupaten Bantul

Pemerintah Kabupaten Bantul telah menyadari bahwa pertumbuhan industri perhotelan di Kabupaten Bantul sudah sangat pesat. Jumlah hotel dan penginapan yang terdata di Dinas Kebudayaan dan Pariwisata Kabupaten Bantul tahun 2010-2015 terdapat 95 hotel dan penginapan. Pesatnya pertumbuhan industri perhotelan tersebut selaras dengan perkembangan sektor pariwisata. Industri perhotelan dan pariwisata adalah dua sektor yang saling melengkapi dan saling mendukung.

Hotel menurut SK Menteri Pariwisata, Pos, dan Telekomunikasi No. KM 37/PW. 340/MPPT-86 dalam Sulastiyono (2011), adalah "Suatu jenis akomodasi yang mempergunakan sebagian atau seluruh bangunan untuk menyediakan jasa penginapan, makanan dan minuman, serta jasa penunjang lainnya bagi umum yang dikelola secara komersial.

Peraturan Menteri Pariwisata Dan Ekonomi Kreatif Republik Indonesia Nomor Pm.53/Hm.001/Mpek/2013 Tentang Standar Usaha Hotel mengamanatkan usaha hotel adalah usaha penyediaan akomodasi berupa kamar-kamar di dalam suatu bangunan, yang dapat dilengkapi dengan jasa pelayanan makan dan minum, kegiatan hiburan dan/atau fasilitas lainnya secara harian dengan tujuan memperoleh keuntungan. Hotel memilih

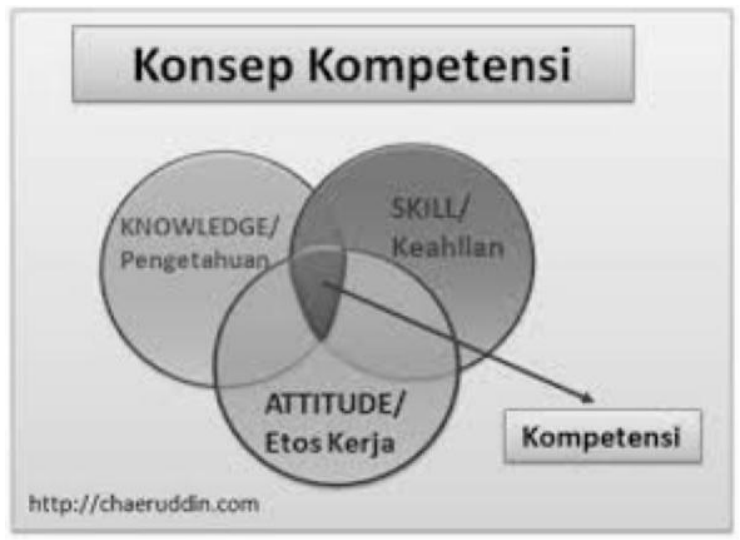

domisilinya di tempat-tempat atau di lingkungan daerah yang memiliki potensi untuk dikunjungi, seperti panorama, adat istiadat masyarakat, sosial, budaya, sebagai pusat pemerintahan, pusat perdagangan, keagamaan dan pusat kegiatan spiritual dan lain-lain.

Apabila suatu hotel atau industri memiliki atau merecruite tenaga kerja yang sudah tersertifikasi hotel akan memiliki benefit atau keuntungan. Karena dicanangkan adanya MEA 2015 pemerintah juga mengeluarkan peraturan baru untuk standart suatu hotel. bahwa suatu usaha atau hotel bila ingin mempertahankan bintang dan kualitasnya maka minimal pada tahun 2015 ini mereka memiliki karyawan yang bersertifikasi Badan Nasional Sertifikasi Profesi (BNSP) minimal 50\% dan pada tahun 2016 minimal $90 \%$. Dengan demikian industry perhotelan sudah tidak ada pilihan lagi kecuali menyiapkan SDM yang memiliki kompetensi bahkan harus secara formal bersertifikat kompetensi yang dikeluarkan Lembaga Sertifikasi Profesi sebagai tangan panjang Badan Nasional Standarisasi Profesi (BNSP).

Industri perhotelan akan lebih memilih calon tenaga kerja yang telah tersertifikasi karena Dalam PP 52 tahun 2012 tentang standar kompetensi dan standar usaha disebutkan pada pasal 12 bahwa Pengusaha Pariwisata wajib mempekerjakan Tenaga Kerja yang telah memiliki Sertifikat Kompetensi di Bidang Pariwisata sesuai dengan ketentuan peraturan perundang-undangan, termasuk tenaga kerja asing.

Adapun sanksi-sanksi dalam PP apabila pengusaha tidak menggunakan karyawan yang bersertifikat kompetensi mulai dari teguran tertulis, pembatasan kegiatan usaha dan pembekuan sementara kegiatan usaha. Inilah yang menjadi dasar mengapa suatu hotel atau industri lebih memilih tenaga kerja yang sudah memiliki sertifikasi kompetensi.

Kondisi tersebut akan mempersempit peluang bagi para lulusan yang kurang memiliki kompetensi bahkan boleh dikatakan bahwa para lulusan Sekolah Menengah Kejuruan (SMK) ataupun lulusan dari Perguruan Tinggi (PT) yang mungkin saja memiliki kompetensi sangat rendah akan menjadi penganggur di negeri sendiri karena kalah bersaing dengan para pendatang dari beberapa negara tetangga terutama yang masuk dalam kelompok Asean yang lebih kompeten. Sedangkan bagi yang sudah menjadi karyawan akan dituntut untuk mendalami kembali ilmunya agar bisa memperoleh pengakuan sebagai tenaga yang berkompetensi agar pemenuhan kebutuhan akan standar kompetensi yang disebutkan dalam PP 52 tahun 2012 dapat segera terpenuhi. Kompetensi menurut konsep Inggris adalah Pengetahuan (knowledge), keterampilan (skill) dan sikap (attitude) yang dimiliki oleh seseorang dalam suatu bidang/ standar tertentu,dan hal itu akan tercermin dalam konteks pekerjaan yang dipengaruhi oleh budaya organisasi dan lingkungan kerja.

Mendapat yang hampir sama dengan konsep Inggris dikemukakan oleh Kravetz (2004), bahwa kompetensi adalah sesuatu yang seseorang tunjukkan dalam kerja setiap hari. Fokusnya adalah pada perilaku di tempat kerja, bukan sifat-sifat kepribadian atau ketrampilan dasar yang ada di luar tempat kerja ataupun di dalam tempat kerja.

Kompetensi mencakup melakukan sesuatu, tidak hanya pengetahuan yang pasif. Seorang karyawan mungkin pandai, tetapi jika mereka tidak meterjemahlkan kepandaiannya ke dalam perilaku di tempat kerja yang efektif, kepandaian tidak berguna. Jadi kompetensi tidak hanya mengetahui apa yang harus dilakukan..Suatu kompetensi adalah apa yang seorang karyawan mampu kerjakan untuk mencapai hasil yang diinginkan dari satu pekerjaan. Kinerja atau hasil yang diinginkan dicapai dengan perilaku ditempat kerja yang didasarkan pada Knowledge Skill Attitude (KSAs). ditunjukkan dengan kerangka berikut 
KSAs $\rightarrow$ Behavior $\rightarrow$ Performance.

Dari kerangka di atas dapat diketahui bahwa secara teoritis KSAs adalah sebagai dasar perilaku di tempat kerja, sedangkan perilaku di tempat kerja yang mengandung unsur-unsur KSAs menghasilkan kinerja. Untuk praktik, sesuatu pekerjaan spesifik harus diidentifikasi kriteria-kriteria utamanya yang kemudian dijabarkan ke dalam dimensi-dimensi dan indikatorindikator kinerja kunci yang harus dicapai berdasarkan standar kinerja yang telah ditetapkan. KSAs di sini adalah merupakan dasar kompetensi kerja yang merupakan kemampuan, kemauan, dan sikap untuk mencapai strandar kinerja yang telah ditetapkan dalam setiap pekerjaan spesifik. Kemampuan, kemauan, dan sikap ini dapat diamati dalam perilaku di tempat kerja dalam seseorang melaksanakan pekerjaannya. Jika hotel adalah yang dimaksud di dalam tempat kerjanya maka, hotelpun masih dibedakan lagi dari mulai hotel non bintang (melati) dan hotel bintang dari hotel bintang satu sampai dengan hotel bintang lima.

Bagian bagian di hotel tersebut menggambarkan betapa rumit dan kompleksnya usaha jasa akomodasi yang disebut hotel terutama hotel dengan predikat bintang lima. Tentunya tidak serumit dan selengkap gambaran tersebut jika kita menemukan hotel dengan predikat bintang satu atau dua, karena ada beberapa departemen yang bisa digabungkan sehingga jumlah bagiannyapun akan mengecil walaupun mungkin fungsinya tetap sama.

Hotel sudah merupakan industri karena disamping merupakan bagian yang integral dari usaha pariwisata dan dapat dikatakan sebagai suatu usaha akomodasi yang dikomersialkan dengan menyediakan fasilitas fasilitas : kamar tamu, makanan dan minuman, pelayanan pelayanan seperti tempat tempat rekreasi, fasilitas olah raga, dan fasilitas dobi, serta kebutuhan sosial seperti keamanan, keramahan dan kenyamanan. Hotel juga merupakan usaha jasa pelayanan yang sangat rumit pengelolaannya (multicomplex) dan seluruh fasilitasnya disediakan/ dibuka untuk umum selama 24 jam.

Hotel termasuk usaha akomodasi. Selain hotel maka Usaha akomodasi juga bisa dibedakan berdasarkan jenis aktivitasnya yaitu seperti Motel, Losmen atau penginapan (Lodgements), Pondok Remaja ( Youth hostels), Bumi Perkemahan (Camping ground), Pondok Wisata atau Wisma ( homestay atau Gusent House), Marina, Jenis jenis akomodasi lain seperti Pondok (Inn)

Di Kabupaten Bantul usaha akomodasi ini berkembang sangat pesat mengikuti perkembangan pariwisata. Jumlah hotel dan penginapan yang ada sudah mencapai 95 buah untuk kelas dengan jumlah kamar medium, namun jika didata semua termasuk penginapan yang berada di lokasi obyek yang hanya memiliki satu kamar, maka jumlahnya mencapai 261 buah dan mungkin saja akan terus berkembang dimasa yang akan datang sejalan dengan munculnya obyek obyek wisata baru.
Pemerintah Kabupaten Bantul mencoba merumuskan strategi pengembangannya dengan melakukan studi identifikasi kebutuhan kompetensi sumber daya manusia bagi industri perhotelan agar bisa memberikan ruang bagi tumbuh dan berkembangnya industri perhotelan di Kabupaten Bantul di masa depan.

\section{LITERATUR REVIEW}

Dalam petunjuk pelaksanaan Peraturan Daerah Kabupaten Bantul No 04 tahun 2014 tentang tanda daftar usaha pariwisata disebutkan bahwa usaha penyediaan akomodasi adalah usaha penyediaan pelayanan penginapan untuk wisatawan yang dapat dilengkapi dengan pelayanan pariwisata lainnya, terdiri atas :

1. hotel adalah penyediaan akomodasi secara harian berupa kamar-kamar didalam 1 (satu) bangunan, yang dapat dilengkapi dengan jasa pelayanan makan dan minum, kegiatan hiburan dan fasilitas lainya;

2. bumi perkemahan adalah penyediaan akomodasi di lama terbuka dengan menggunakan tenda;

3. persinggahan caravan adalah penyediaan tempat untuk kendaraan yang dilengkapi dengan fasilitas menginap di alam terbuka dapat dilengkapi dengan kendaraanya;

4. vila adalah penyediaan akomodasi berupa keseluruhan bangunan tunggal yang dapat dilengkapi dengan fasilitas, kegiatan hiburan serta fasilitas lainya;

5. pondok wisata adalah penyediaan akomodasi berupa bangunan rumah tinggal yang dihuni oleh pemiliknya dan dimanfaatkan sebagian untuk disewakan dengan memberikan kesempatan kepada wisatawan nuntuk berinteraksi dalam kehidupan sehari hari pemiliknya; dan

6. akomodasi lain adalah termasuk motel, sub jenis usaha lainya dari jenis usaha akomodasi lain yang ditetapkan oleh Bupati, Walikota dan Gubernur.

Hotel menurut SK Menteri Pariwisata, Pos, dan Telekomunikasi No. KM 37/PW. 340/MPPT-86 dalam Sulastiyono (2011), adalah "Suatu jenis akomodasi yang mempergunakan sebagian atau seluruh bangunan untuk menyediakan jasa penginapan, makanan dan minuman, serta jasa penunjang lainnya bagi umum yang dikelola secara komersial.

a. Hotel Bintang adalah hotel yang telah memenuhi kriteria penilaian penggolongan kelas hotel bintang satu, dua, tiga, empat, dan bintang lima.

b. Hotel Nonbintang adalah hotel yang tidak memenuhi kriteria penilaian penggolongan kelas hotel sebagai hotel bintang satu.

c. Produk Usaha Hotel adalah fasilitas akomodasi berupa kamar-kamar yang dapat dilengkapi dengan jasa pelayanan makan dan minum, dan/atau fasilitas lainnya.

d. Pelayanan Usaha Hotel adalah suatu proses yang memberikan kemudahan melalui prosedur standar 
pelayanan. (Permen Pariwisata dan Ekonomi Kreatif No PM. 53/HM.001/MPEK/2013)

\section{Departemen Departemen Hotel}

Semakin besar hotel atau sebutan bintang yang disandangnya maka akan semakin banyaklah departemennya. Secara umum hotel berbintang lima biasanya memiliki 9 Departemen, antara lain sebagai berikut :

\section{Front Office Department}

Front Office Department adalah departemen hotel yang tugasnya berhubugan lagsung dengan tamu, menerima pemesanan kamar tamu, menerima pendaftaran tamu, maupun memberikan informasi yang diinginkan tamu. Departemen ini merupakan kesan pertama bagi tamu ketika tamu hendak check in.

Adapun seksi-seksi di Front Office Departement terdiri dari : reservation, reception, telephone operator. front office cashier, uniform service/concierge, information section, guest relation officer

\section{Food and Beverage Department}

Food and Beverage department adalah departemen hotel yang menangani hal-hal yang berkaitan dengan mengolah menyediakan makanan dan minuman serta bertugas memberikan pelayanan kepada tamu pada saat makan di restaurant. Food \& Beverage Department dibagi beberapa bagian diantara lain (1) Food \& Beverage Production Food \& Beverage Production adalah suatu bagian yang bertugas mengolah bahan makanan menjadi bahan matang untuk disediakan kepada para tamunya (2) Food \& Beverage Service Food \& Beverage Service adalah suatu bentuk pelayanan berupa pengantaran order tamu. Food \& Beverage Service dibagi menjadi dua bagian lagi yaitu; food service, beverage service

\section{Housekeeping Department}

Housekeeping department adalah departemen hotel yang bertanggung jawab atas seluruh kebersihan hotel baik dalam ruangan maupun public area serta membersihkan berbagai fasilitas hotel. Housekeeping terbagi atas beberapa seksi antara lain : floor section, public area section, linen/uniform section, laundry section (valet, washer, presser, marker, checker), gardener section, florist section, recreation/swimmimg pool section

4. Accounting department:

Accounting departement adalah suatu departemen hotel yang bertanggung jawab atas masalah administrasi hotel baik pengeluaran maupun pendapatan keuangan di hotel.

5. Personalia/HRD Department:

Personalia Departemen adalah suatu departemen hotel yang bertugas menerima dan menempatkan karyawan/trainee. serta menangani masalah yang dihadapi karyawan.

\section{Engineering Department}

Engineering Department adalah suatu departemen hotel yang bertanggung jawab untuk menangani perawatan maupun perbaikan atas semua alat-alat serta mesin yang ada di hotel apabila mengalami kerusakan.

\section{Marketing department}

Marketting departement adalah suatu bagian yang bertugas memasarkan hotel kepada masyarakat maupun pelanggan agar setiap tahunnya mengalami peningkatan atas tamu-tamu yang menginap dan menggunakan fasilitas-fasilitas hotel.

\section{Purchasing department:}

Purchasing departemen adalah suatu bagian yang bertanggung jawab atas keseluruhan pembelian pengadaan serta semua kebutuhan hotel.

\section{Security Department:}

Security Department adalah suatu bagian yang bertugas menjaga keamanan hotel maupun tamu selama menginap ( 24 jam)

\section{Kompetensi}

Kompetensi pada umumnya diartikan sebagai kecakapan, keterampilan, kemampuan. Kata dasarnya kompeten, berarti cakap, mampu atau terampil. Pada konteks manajemen sumber daya manusia, istilah kompetensi mengacu kepada atribut/karakteristik seseorang yang membuatnya berhasil dalam pekerjaan. Banyak pihak sering menggunakan istilah kompetensi sebagai kemampuan seseorang untuk berkinerja (the ability to perform). Hal ini dikarenakan efektif tidaknya suatu hasil pekerjaan sangat dipengaruhi oleh keterampilan, pengetahuan, perilaku (sikap) dan kemampuan yang sesuai dengan tuntutan pekerjaan.

Kompetensi menyangkut kewenangan setiap individu untuk melakukan tugas atau mengambil keputusan sesuai dengan peranannya dalam organisasi yang relevan dengan keahlian, pengetahuan, dan kemampuan yang dimiliki. Rivai (2009) mengatakan kompetensi yang dimiliki karyawan secara individual harus mampu mendukung pelaksanaan strategi organisasi dan mampu mendukung setiap perubahan yang dilakukan manajemen. Dengan kata lain, kompetensi yang dimiliki individu dapat mendukung sistem kerja berdasarkan tim. Dengan demikian, untuk mewujudkan keberhasilan program-program yang telah ditetapkan oleh suatu organisasi, maka setiap karyawan di dalamnya diharuskan memiliki standar kompetensi yang diperlukan.

Menurut Simamora (2004), kompetensi adalah jenis keahlian, pengetahuan, dan kemampuan yang diperlukan untuk menunaikan sebuah pekerjaan secara efektif. Kemudian Wibowo (2007), menyatakan kompetensi adalah suatu kemampuan untuk 
melaksanakan atau melakukan suatu pekerjaan atau tugas yang dilandasi atas keterampilan dan pengetahuan serta di dukung oleh sikap kerja yang dituntut oleh pekerjaan tersebut.

Menurut Spencer dan Spencer dalam Tjutju dan Suwatno (2009:23), menyatakan bahwa ada lima karakteristik kompetensi, yaitu sebagai berikut:

1. Keterampilan (Skill) : Kemampuan untuk mampu melaksanakan tugas-tugas fisik dan mental tertentu.

2. Pengetahuan (Knowledge) : Suatu informasi yang dimiliki seseorang khususnya pada bidang spesifik. Pengetahuan merupakan kompetensi yang kompleks.

3. Konsep Diri (SelfConcepts): Konsep diri adalah sikap atau nilai, atau self image dari orang-orang. Konsep diri yaitu semua ide, pikiran, kepercayaan dan pendirian yang diketahui individu tentang dirinya dan mempengaruhi individu dalam berhubungan dengan orang lain.

4. Motif (Motive): Apa yang secara konsisten dipikirkan atau keinginan-keinginan yang menyebabkan melakukan tindakan. Apa yang mendorong perilaku yang mengarah dan dipilih terhadap kegiatan atau tujuan tertentu.

5. Sifat (Traits): Ciri fisik dan reaksi-reaksi yang bersifat konsisten terhadap situasi atau informasi.

Jenis kompetensi menurut Spencer dan Spencer (1993), mengklasifikasikan dimensi dan komponen kompetensi individual menjadi tiga, yaitu: (1). Kompetensi intelektual, (2). Kompetensi emosional, (3). Kompetensi sosial. Urain dari masing-masing kompetensi secara rinci dijelaskan sebagai berikut:

Kompetensi Intelektual

Kompetensi intelektual adalah karakter sikap dan perilaku atau kemauan dan kemampuan intelektual individu (dapat berupa pengetahuan, keterampilan, pemahaman professional, pemahaman konstektual, dan lain-lain) yang bersifat relatif stabil ketika menghadapi permasalahan di tempat kerja, yang dibentuk dari sinergi antara watak, konsep diri, motivasi internal, serta kapasitas pengetahuan kontekstual. Kapasitas intelektual adalah kemampuan yang diperlukan untuk menjalankan kegiatan mental. Kompetensi intelektual ini terinternalisasi dalam bentuk sembilan kompetensi sebagai berikut:

1. Berprestasi, kemauan atau semangat seorang karyawan untuk berusaha mencapai kinerja yang terbaik dengan menetapkan tujuan yang menantang serta menggunakan cara yang lebih baik secara terus-menerus.

2. Kepastian Kerja, kemauan dan kemampuan seorang karyawan untuk meningkatkan kejelasan kerja dengan menetapkan rencana yang sistematik dan mampu memastikan pencapaian tujuan berdasarkan data atau informasi yang akurat.

3. Inisiatif, kemauan seorang karyawan untuk bertindak melebihi tuntutan seseorang, atau sifat keinginan untuk mengetahui hal-hal yang baru dengan mengevaluasi, menyeleksi, dan melaksanakan berbagai metode dan strategi untuk meningkatkan kinerja. Inisiatif juga sangat berkaitan erat dengan konsep kreativitas, yaitu kompetensi yang berhubungan dengan kemampuan seorang karyawan untuk berfikir dan bertindak secara berbeda dari kebiasaan dan lebih efektif. Dimensi dari kreativitas ini memiliki empat sifat atau ciri yaitu: (a). Peka terhadap masalah, (b). Kaya akan gagasan / alternatif pemecahan, (c). Mampu menghasilkan ide asli, dan (d). Memiliki sikap fleksibilitas (bersedia mempertimbangkan berbagai gagasan).

4. Penguasaan Informasi, kepedulian seorang karyawan untuk meningkatkan kualitas keputusan dan tindakan berdasarkan informasi yang handal dan akurat serta berdasarkan pengalaman dan pengetahuan atas permasalahan kondisi lingkungan kerja.

5. Berfikir Analitik, kemampuan seorang karyawan untuk memahami situasi dengan cara menguraikan permasalahan menjadi komponen-komponen yang lebih rinci serta menganalisis permasalahan secara sistematik berdasarkan pendekatan logis.

6. Berfikir Konseptual, kemampuan seorang karyawan untuk memahami dan memandang suatu permasalahan sebagai satu kesatuan yang meliputi kemampuan yang memahami akar permasalahan.

7. Keahlian Praktikal, Kemampuan seorang karyawan menguasai pengetahuan eksplisit berupa keahlian untuk menyelesaikan pekerjaan serta kemauan untuk memperbaiki dan mengembangkan diri sendiri.

8. Kemampuan Linguistik, Kemampuan seorang karyawan untuk menyampaikan pemikiran atau gagasan secara lisan atau tulis untuk kemudian di diskusikan atau di dialogkan sehingga terbentuk kesamaan persepsi.

9. Kemampuan Naratif, kemampuan seorang karyawan untuk menyampaikan pokok-pokok pikiran dan gagasan dalam suatu pertemuan formal atau informal dengan menggunakan media cerita.

\section{Kompetensi Emosional}

Kompetensi emosional adalah karakter sikap dan perilaku atau kemauan dan kemampuan untuk menguasai diri dan memahami lingkungan secara objektif sehingga pola emosinya relatif stabil ketika menghadapi berbagai permasalahan di tempat kerja. Kompetensi emosional individu terinternalisasi dalam bentuk enam tingkat kemauan dan kemampuan sebagai berikut:

1. Sensitivitas atau Saling Pengertian, kemampuan dan kemauan seorang karyawan untuk memahami, mendengarkan, dan menanggapi hal-hal yang tidak dikatakan orang lain, yang bisa berupa pemahaman atas pemikiran dan perasaan serta kelebihan dan keterbatasan orang lain. 
2. Pengendalian Diri, kemampuan seorang karyawan untuk mengendalikan prestasi dan emosi pada saat menghadapi tekanan sehingga tidak melakukan tindakan yang negatif dalam situasi apapun.

3. Percaya Diri, keyakinan seorang karyawan untuk menunjukkan citra diri, keahlian, kemampuan serta pertimbangan yang positif.

4. Kemampuan Beradaptasi, kemampuan seorang karyawan menyesuaikan diri dan bekerja secara efektif pada berbagai situasi.

5. Komitmen Pada Organisasi, kemampuan seorang karyawan untuk mengikatkan diri terhadap visi dan misi organisasi dengan memahami kaitan antara tanggung jawab pekerjaannya dengan tujuan organisasi secara keseluruhan.

Kompetensi Sosial

Kompetensi sosial adalah karakter sikap dan perilaku atau kemauan untuk membangun simpul-simpul kerja sama dengan orang lain ketika menghadapi permasalahan di tempat kerja. Kompetensi sosial individu terinternalisasi dalam bentuk tujuh tingkat kemauan dan kemampuan, sebagai berikut:

1. Pengaruh dan Dampak, kemampuan seorang karyawan meyakinkan dan mempengaruhi orang lain untuk secara efektif dan terbuka dalam berbagi pengetahuan, pemikiran dan ide-ide secara perorangan atau dalam kelompok agar mau mendukung gagasan atau idenya.
2. Kesadaran Berorganisasi, kemampuan seorang karyawan untuk memahami posisi dan kekuasaan secara komprehensif.

3. Membangun Hubungan Kerja, kemampuan seorang karyawan untuk membangun dan memelihara jaringan kerja sama agar tetap hangat dan akrab.

4. Mengembangkan Orang Lain, kemampuan seorang karyawan untuk meningkatkan keahlian bawahan atau orang lain dengan memberikan umpan balik yang bersifat membangun berdasarkan fakta yang spesifik serta memberikan pelatihan, dan memberi wewenang untuk memberdayakan dan meningkatkan partisipasinya.

5. Mengarahkan Bawahan, kemampuan seorang karyawan memerintah, mempengaruhi, dan mengarahkan bawahan dengan melaksanakan strategi dan hubungan interpersonal agar mereka mau mencapai tujuan yang telah ditetapkan.

6. Kerja Tim, keinginan dan kemampuan seorang karyawan untuk bekerja sama dengan orang lain secara koperatif yang menjadi bagian yang bermakna dari suatu tim untuk mencapai solusi yang bermanfaat bagi semua pihak.

7. Kepemimpinan Kelompok, keinginan dan kemampuan seorang karyawan untuk berperan sebagai pemimpin kelompok dan mampu menjadi suri teladan bagi anggota kelompok yang dipimpinnya. 


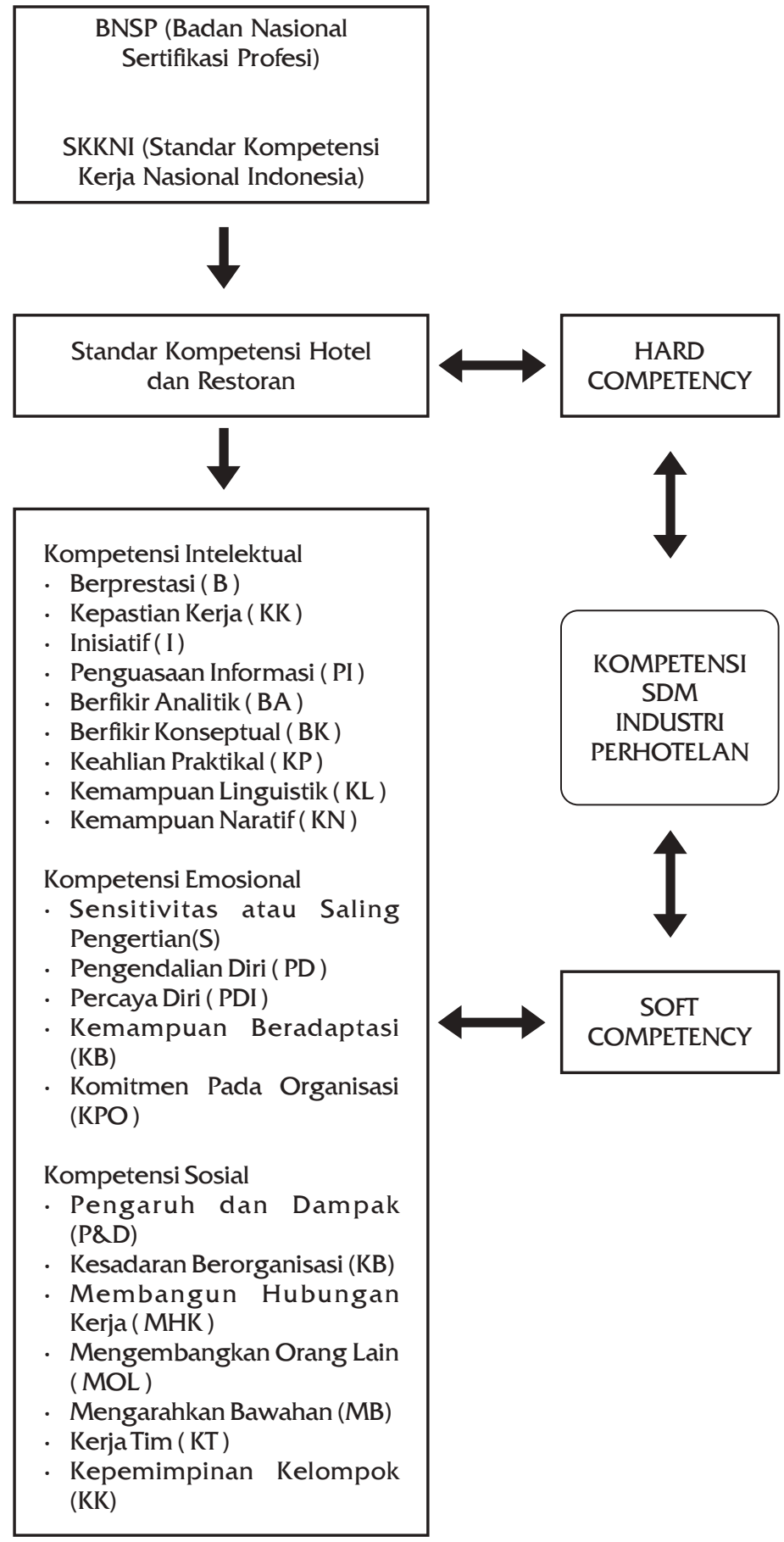

Spencer \& Spencer Jr. 


\section{METODE PENELITIAN}

Jenis Penelitian

Adapun metode yang digunakan dalam Kegiatan Studi Identifikasi Kebutuhan Kompetensi SDM bagi Industri Perhotelan di Kabupaten Bantul menggunakan metode deskriptif kualitatif, yaitu dengan menggunakan data primer dan data sekunder untuk kemudian dilakukan pengolahan data.

Subyek/obyek penelitian

1. Populasinya semua pemilik atau karyawan dan tamu hotel/penginapan di kabupaten Bantul.

2. Responden diambil berdasarkan purposive sampling, dengan jumlah sampelnya 30 orang pemilik atau pegawai hotel dan 30 orang lagi adalah tamu hotel/ penginapan di Kabupaten Bantul.

Teknik Pengumpulan Data

Arikunto (2002)" metode penelitian adalah cara yang digunakan oleh peneliti dalam pengumpulan data penelitiannya ". Berdasarkan pengertian tersebut dapat dikatakan bahwa metode penelitian adalah cara yang dipergunakan untuk mengumpulkan data yang di perlukan dalam penelitian. Teknik yang digunakan dalam penelitian ini adalah :

\section{Kuesioner/angket}

Pengertian metode angket menurut Arikunto (2006)

"Angket adalah pernyataan tertulis yang digunakan untuk memperoleh informasi dari responden dalam arti laporan tentang pribadi atau hal-hal yang ia ketahui". Sedangkan menurut Sugiyono (2008:199) "Angket atau kuesioner merupakan tehnik pengumpulan data yang dilakukan dengan cara memberi seperangkat pertanyaan atau pernyataan tertulis kepada responden untuk dijawab". Kuesioner atau angket yang digunakan dalam penelitian ini adalah jenis kuesioner atau angket langsung yang tertutup karena responden hanya tinggal memberikan tanda pada salah satu jawaban yang dianggap benar.

\section{Dokumentasi}

Menurut Arikunto (2006) "Dokumentasi adalah mencari dan mengumpulkan data mengenai hal-hal yang berupa catatan, transkip, buku, surat kabar, majalah, notulen, rapot, agenda dan sebagainya."

Metode Analisis

Metode Analisis yang digunakan adalah metode analisis Kompetensi Spencer \& Spencer khususnya untuk kompetensi Non teknis atau soft competency hal ini dilakukan dengan mempertimbangkan bahwa kompetensi teknis (hard competency) sudah ditetapkan oleh Badan Nasional Sertifikasi Profesi dalam bentuk Standar Kompetensi Kerja Nasional Indonesia (SKKNI) bidang Hotel dan Restoran. SKKNI adalah rumusan kemampuan kerja yang mencakup aspek pengetahuan, keterampilan dan/atau keahlian serta sikap kerja yang relevan dengan pelaksanaan tugas dan syarat jabatan yang ditetapkan sesuai dengan ketentuan peraturan perundang-undangan.

Untuk menentukan level tidak kompeten sampai sangat kompeten digunakan model Analisis Spencer, sekaligus memberi peringkat level item kompetensi yang diperlukan dalam industry perhotelan.

Validasi Kompetensi dan Pemetaan Kompetensi

Dari hasil penelitian diperoleh data kebutuhan nyata kompetensi Industri Perhotelan yang kemudian disusun ulang dan dipilih berdasarkan skala prioritas Linkert antara 1 -4. Para responden yang terlibat dalam proses terdiri dari karyawan hotel dan tamu hotel yang masing masing berjumlah 30 orang responden. Langkah selanjutnya dengan menggunakan Pedoman kompetensi yang berlaku di Indonesia dari standar kompetensi kerja nasional khususnya bidang Hotel dan Restoran, hasil penelitian dipetakan untuk memperoleh kebutuhan kompetensi SDM bagi industri perhotelan.

\section{HASIL PENELITIAN DAN PEMBAHASAN}

Dari data yang terkumpul akan dikelompokkan menjadi dua data yaitu data dari responden kelompok Tenaga Kerja atau pemilik dan data dari responden kelompok tamu sebagai penyewa kamar.

Hasil questioner dipilih berdasar skala prioritas Likert antara 1-4 dari para responden yang meliputi tenaga front office, tenaga housekeeping dan tenaga yang merangkap keduanya, tenaga yang menyiapkan makanan dan minuman serta beberapa para pemilik atau manajer yang berjumlah 30 orang. 
Tabel 1. Analisis hasil Validasi Kabutuhan Kompetensi Bidang Hotel.

\begin{tabular}{|c|c|c|c|c|c|c|c|c|c|c|c|}
\hline & & SOFT & & Linl & & & rsen/ & link & & Total & \\
\hline & KOMPETENSI INTELEKTUAL & COMPETENCY & 12 & 23 & 4 & 1 & 2 & 3 & 4 & $\%$ & AVG \\
\hline & 1. Mempunyai kemauan belajar agar bisa bekerja lebih baik & Keahlian Praktikal & $0 \mid 0$ & 0 & 46 & 0 & 0 & 80 & 20 & 100 & 3.2 \\
\hline & $\begin{array}{l}\text { 2. Semua tindakan di dasari oleh informasi yang benar dan akurat } \\
\text { 3. Bekerja di dasari oleh pengalaman dan pengetahuan lingkungan kerja }\end{array}$ & Penguasaan Informasi & 03 & 32 & 25 & 0 & 10 & 73 & 17 & 100 & 3.07 \\
\hline & 4. Selalu mempunyai gagasan yang baik & & & & & & & & & & , \\
\hline & 5. Bersikap fleksibel & Inisiatif & 01 & 12 & 27 & 0 & 3 & 73 & 23 & 100 & 3.17 \\
\hline & 6. Berani mengemukakan pemikiran di dalam pertemuan pertemuan & Kemampuan Naratif & 02 & 22 & 26 & 0 & 6 & 73 & 20 & 100 & 3.11 \\
\hline & 7. Mudah menyampaikan gagasan secara langsung kepada orang lain & Keahlian Linguistik & 02 & 220 & 8 & 0 & 6 & 67 & 27 & 100 & 3.21 \\
\hline & 8. Mencari solusi terhadap permasalahan dengan mencari akar penyebab & Berpikir Konseptual & 03 & 320 & 0 & 0 & 10 & 67 & 23 & 100 & 3.13 \\
\hline & 9. Mau dan mampu membuat rencana yang sistematik & & & & & & & & & & \\
\hline & 10. Bisa memastikan hasil pekerjaan berdasar data dan informasi & Kepastian Kerja & 01 & 1 1 19 & 910 & 0 & 3 & 63 & 34 & 100 & 3.31 \\
\hline & 11. Sebelum bertindak selalu memikirkan akibatnya & Berpikir Analitik & 00 & $0 \mid 18$ & 812 & 0 & 0 & 60 & 40 & 100 & 3.40 \\
\hline Soft & $\begin{array}{l}\text { 12. Mempunyai semangat kerja tinggi untuk mencapai hasil terbaik } \\
\text { 13. Selalu menetapkan tujuan kerja yang menantang } \\
\text { 14. Memperbaiki cara bekerja secara terus menerus }\end{array}$ & Berprestasi & $0 \mid 3$ & & $7 \mid 10$ & 0 & 10 & 57 & 33 & 100 & 3,23 \\
\hline Competency & & & & linke & & & rsen/ & link & sert & Total & \\
\hline & KOMPETENSI EMOSIONAL & & 12 & 23 & 4 & 1 & 2 & 3 & 4 & $\%$ & AVG \\
\hline & 1. Pemahaman terhadap Visi, Misi serta Tujuan Perusahaan sangat baik & Komitmen pd organisasi & 0 & 026 & 64 & 0 & 0 & 87 & 13 & 100 & 3.13 \\
\hline & 2. Bersedia memahami pikiran dan perasaan orang lain & Sensivitas & 0 & $0 \quad 25$ & 5 & 0 & 0 & 83 & 17 & 100 & 3.17 \\
\hline & 3. Mempunyai keyakinan akan kemampuan melaksanakan tugas. & Percaya Diri & 0.1 & 12 & 43 & 0 & 3 & 80 & 10 & 100 & 2.86 \\
\hline & 4. Mampu menyesuaikan diri dengan keadaan dan situasi apapun & Kemampuasn Beradaptasi & 0.1 & 12 & 45 & 0 & 3 & 80 & 17 & 100 & 3.14 \\
\hline & 5. Mampu mengendalikan diri saat menghadapi banyak tekanan & Pengendalian Diri & $0: 2$ & & 35 & 0 & 6 & 77 & 17 & 100 & 3.05 \\
\hline & & & & & & & & Link & kert & Total & \\
\hline & KOMPETENSI SOSIAL & & 1 & 23 & 4 & 1 & 2 & 3 & 4 & $\%$ & AVG \\
\hline & 1. Saudara mampu memimpin dan menjadi tauladan rekan kerja & Kepemimpinan Kelompok & 0.1 & 127 & 72 & 0 & 3 & 90 & 6 & 100 & 3.00 \\
\hline & 2. Saudara Mampu mempengaruhi orang lain agar bekerja lebih giat & Mengarahkan Bawahan & 0 & 22 & 62 & 0 & 6 & 87 & 6 & 100 & 2.97 \\
\hline & 3. Saudara lebih mementingkan keberhasilan secara tim & Kerja Tim & 0. & 125 & 54 & 0 & 3 & 83 & 13 & 100 & 3.04 \\
\hline & $\begin{array}{l}\text { 4. Saudara menghormati rekan kerja tanpa membedakan jabatan/golong. } \\
\text { 5: Saudara siap membantu rekan kerja dalam pekerjaan atau lainnya }\end{array}$ & Kesadaran Berorganisasi & 0 & 22 & 35 & 0 & 6 & 77 & 17 & 100 & 3.05 \\
\hline & 6. Saudara Dapat membangun hubungan kerja positif thd semua karyawan & Membangun Hubungan Kerja & 0 & $0 \longdiv { 2 }$ & 37 & 0 & 0 & 77 & 23 & 100 & 3.23 \\
\hline & 7. Saudara mempunyai kompetensi membantu kemampuan kerja Karyawan & Mengembangkan orang lain & 0 & & 37 & 0 & 0 & 77 & 23 & 100 & 3.23 \\
\hline & 8. Saudara mampu berkomunikasi dengan baik terhadap rekan kerja & Pengaruh \& Dampak & $0: 2$ & & 26 & 0 & 6 & 73 & 20 & 100 & 3.11 \\
\hline
\end{tabular}

Dari tabel diatas dapat dijelaskan beberapa uraian sebagai berikut.

1. Dari kompetensi intelektual sebanyak 14 elemen hanya bernilai 'penting', sementara yang bernilai 'sangat penting' tidak terdapat sama sekali. Urutan penting menurut para pekerja atau pemilik adalah keahlian praktikal berturut turut penguasaan informasi, inisiatif, kemampuan naratif sampai dengan urutan paling bawah adalah berprestasi.

2. Dari 5 kompetensi Emosional juga tidak terdapat kompetensi yang bernilai 'sangat penting' tetapi seluruhnya hanya bernilai 'penting' saja. Urutan yang menjadi prioritas responden adalah Komitmen pada organisasi, sensitivitas, percaya diri kemampuan beradaptasi, dan pengendalian diri.
3. Dari kompetensi sosial yang berjumlah 8 elemen, juga diperoleh kompetensi bernilai 'penting' sedangkan yang bernilai 'sangat penting' juga tidak terdapat. Urutan prioritas menurut mereka adalah kepemimpinan kelompok, mengarahkan bawahan dan kerja tim.

\section{PEMBAHASAN DAN PEMETAAN}

Dengan berpedoman pada Hard Competency yang merupakan Standar Nasional khususnya bidang Hotel dan Restoran dan dilengkapi dengan hasil penelitian menggunakan kuesioner Spencer \& Spencer yang merupakan Soft Competency maka akan dipetakan kebutuhan Kompetensi SDM bagi Industri Perhotelan di Kabupaten Bantul Yogyakarta. 
Tabel 2. Gap Competency Tenaga Perhotelan di Bantul Hasil Validasi

\begin{tabular}{|l|c|c|c|c|c|c|c|c|}
\hline SOFT COMPETENCY & 1 & 2 & 3 & 4 & $\%$ & Rata2 & $\begin{array}{c}\text { Kesenjangan } \\
\text { (Gap) }\end{array}$ & $\begin{array}{c}\text { Prioritas } \\
\text { Kebutuhan } \\
\text { sd }\end{array}$ \\
\hline & & & & & & & \\
\hline Keahlian Praktikal & 0 & 0 & 80 & 20 & 100 & 3,2 & 0,80 & 15 \\
\hline Penguasaan Informasi & 0 & 10 & 73 & 17 & 100 & 3,07 & 0,93 & 7 \\
\hline Inisiatif & 0 & 3 & 73 & 23 & 100 & 3,17 & 0,83 & 13 \\
\hline Kemampuan Naratif & 0 & 6 & 73 & 20 & 100 & 3,11 & 0,89 & 8 \\
\hline Keahlian Linguistik & 0 & 6 & 67 & 27 & 100 & 3,21 & 0,79 & 16 \\
\hline Berpikir Konseptual & 0 & 10 & 67 & 23 & 100 & 3,13 & 0,87 & 10 \\
\hline Kepastian Kerja & 0 & 3 & 63 & 34 & 100 & 3,31 & 0,69 & 20 \\
\hline Berpikir Analitik & 0 & 0 & 60 & 40 & 100 & 3.40 & 0,60 & 21 \\
\hline Berprestasi & 0 & 10 & 57 & 33 & 100 & 3,23 & 0,77 & 17 \\
\hline Komitmen pd organisasi & 0 & 0 & 87 & 13 & 100 & 3,13 & 0,87 & 11 \\
\hline Sensivitas & 0 & 0 & 83 & 17 & 100 & 3,17 & 0,83 & 14 \\
\hline Percaya Diri & 0 & 3 & 80 & 10 & 100 & 2,86 & 1,14 & 1 \\
\hline Kemampuan Beradaptasi & 0 & 3 & 80 & 17 & 100 & 3,14 & 0,86 & 12 \\
\hline Pengendalian Diri & 0 & 6 & 77 & 17 & 100 & 3,05 & 0,95 & 5 \\
\hline Kepemimpinan Kelompok & 0 & 3 & 90 & 6 & 100 & 3.00 & 1,00 & 3 \\
\hline Mengarahkan Bawahan & 0 & 6 & 87 & 6 & 100 & 2,97 & 1,03 & 2 \\
\hline Kerja Tim & 0 & 3 & 83 & 13 & 100 & 3,04 & 0,96 & 4 \\
\hline Kesadaran Berorganisasi & 0 & 6 & 77 & 17 & 100 & 3,05 & 0,95 & 6 \\
\hline Membangun Hubungan Kerja & 0 & 0 & 77 & 23 & 100 & 3,23 & 0,77 & 18 \\
\hline Mengembangkan orang lain & 0 & 0 & 77 & 23 & 100 & 3,23 & 0,77 & 19 \\
\hline Pengaruh \& Dampak & 0 & 6 & 73 & 20 & 100 & 3,11 & 0,89 & 9 \\
\hline
\end{tabular}

Melihat tabel di atas bisa dijelaskan bahwa ukuran kompetensi dirancang mulai dari yang paling penting nilainya adalah 4 , penting nilainya 3 , dan kurang penting nilainya 2 serta tidak penting sekali nilainya 1 . Sehingga bisa dikata-kan bahwa kesenjangan kompetensi dari yang lebih besar sampai dengan yang paling kecil, menunjukkan bahwa upaya peningkatan SDM seyogyanya diprioritaskan sesuai dengan urutan nilai gapnya paling besar.

Tabel tersebut mengisyaratkan bahwa prioritas peningkatan Kompetensi bidang hotel utamanya pada soft competency dimulai dari upaya meningkatkan percaya diri yang masuk dalam ranah kompetensi Emosional yaitu dengan gap sebesar 1,14, kemudian disusul dengan teknik mengarahkan bawahan dimana memiliki gap sebesar 1,03. Selanjutnya Kepemimpinan Kelompok menduduki urutan prioritas ke tiga dengan gap sebesar 1,00 dan Kerja Tim diurutan ke empat dengan gap sebesar 0,96 , ketiganya masuk dalam ranah Kompetensi Sosial. Sedangkan Kesenjangan terkecil berada pada ranah Intelektual yang diawali pada Berpikir analitik dengan gap 0,60, sedangkan kepastian kerja dengan gap 0,69. Demikian seterusnya.

Dari data lapangan yang terkumpul berupa respon kuisioner Spencer \& Spencer yang dibagikan kepada 30 responden kemudian dikaji dengan skala Linkert dengan menggunakan prosen kemudian dibuat rangking untuk menemukan kondisi kompetensi riil. Hasil prosen Linkert kemudian dihitung rata ratanya yang dibandingkan dengan skala tertinggi 'paling penting' yaitu 4 untuk menemukan gap atau kesenjangan kompetensi. Dari rangking nilai gap terkecil tersebut sampai nilai gap terbesar maka ditemukan besaran kesenjangan kompetensi. Kompetensi dimaksud dalam kesenjangan ini adalah soft kompetensi adalah sebagai berikut:

1. Semua respon menunjukkan bahwa kompetensi SDM berdasar kuisioner hanya memiliki nilai 'penting' saja yang artinya belum maksimal karena masih ada kesenjangan. Oleh karena itu semua kompetensi yang dikelompokkan menjadi tiga kelompok kompetensi dengan kelompok yang berjumlah 14 butir pertanyaan yang masuk dalam 9 soft kompetensi intelektual, kelompok yang berjumlah 5 butir pertanyaan yang masuk dalam soft kompetensi emosio-nal dan kelompok yang berjumlah 8 butir yang masuk dalam 7 soft kompetensi sosial, masih membutuhkan upaya yang lebih keras lagi untuk dapat meningkat kompetensinya.

2. Urutan prioritas kebutuhan peningkatan kompetensi SDM dimulai dari kompetensi yang memiliki nilai gap yang paling besar menuju gap yang paling kecil

Kebutuhan Kompetensi Tenaga Perhotelan di Bantul

Penggabungan kompetensi antara hard kompetensi dari Standar Kompetensi Tenaga Profesi yang dikeluarkan oleh Badan Nasional Sertifikasi Profesi dengan soft kompetensi hasil pemetaan dari kondisi tenaga perhotelan di Bantul yang menggunakan pedoman Spencer \& Spencer akan memberikan gambaran kompe-tensi ideal tenaga bidang perhotelan yangdibutuh-kan di Kabupaten Bantul. Gambaran Seleng-kapnya dapat di lihat dalam tabel berikut ini 


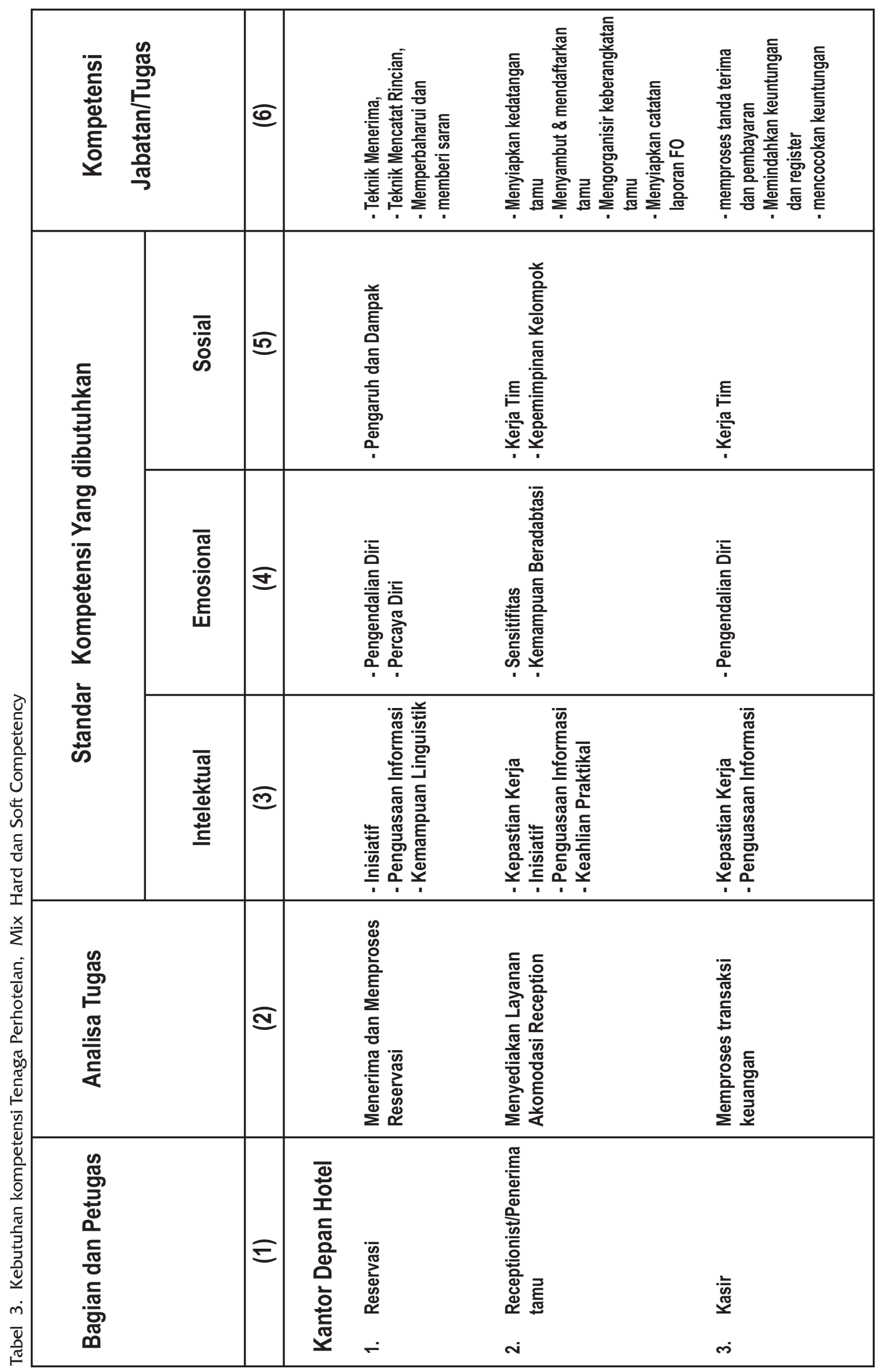




\begin{tabular}{|c|c|c|c|c|c|c|}
\hline 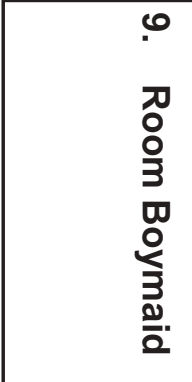 & 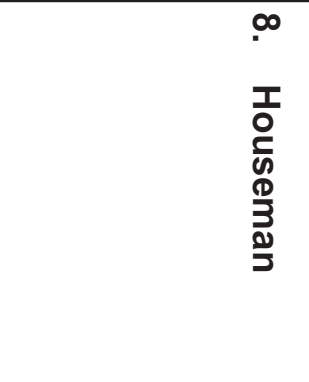 & 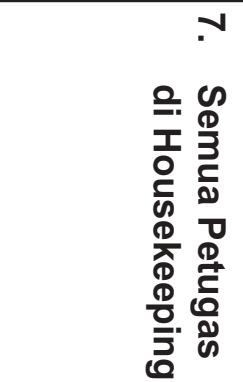 & 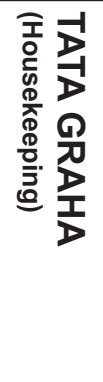 & 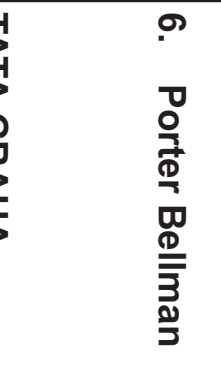 & 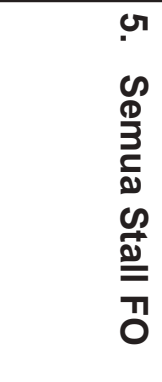 & 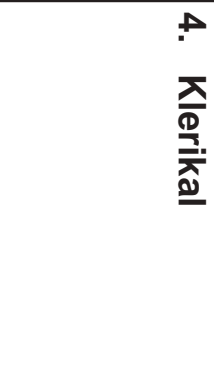 \\
\hline 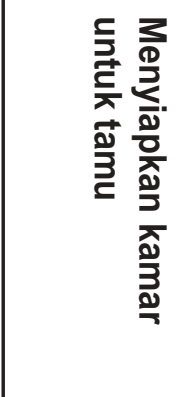 & 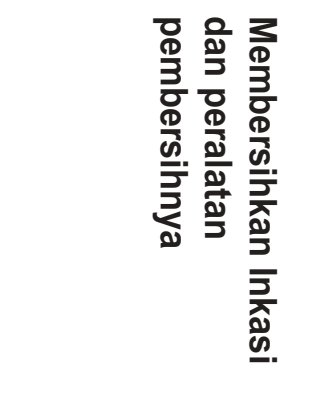 & 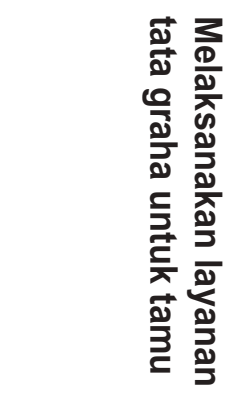 & & 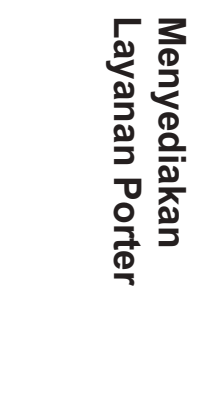 & 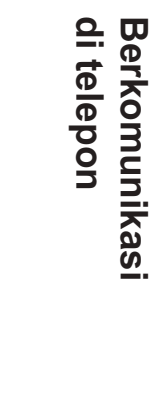 & 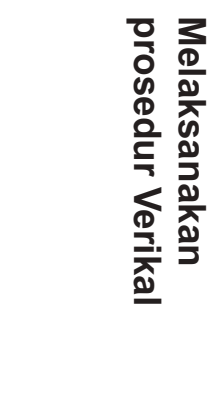 \\
\hline 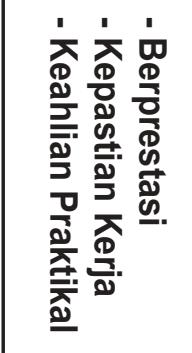 & 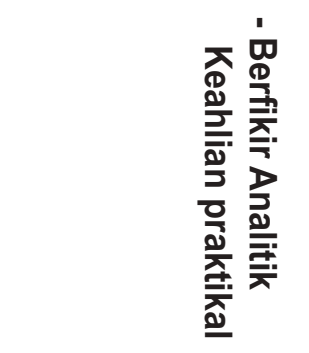 & 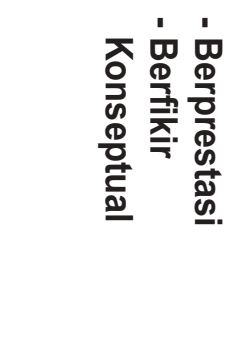 & & 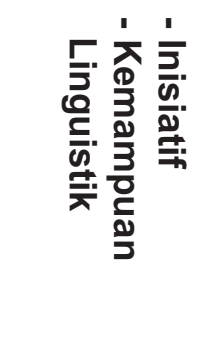 & 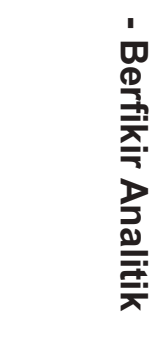 & 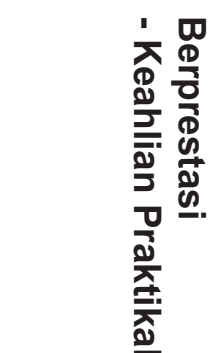 \\
\hline 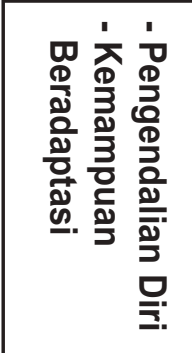 & 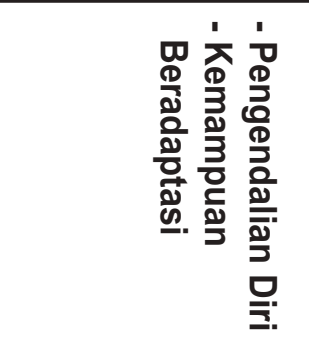 & 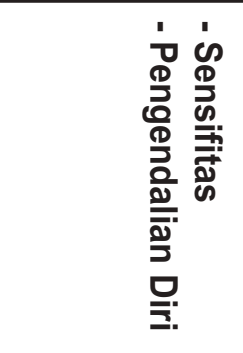 & & 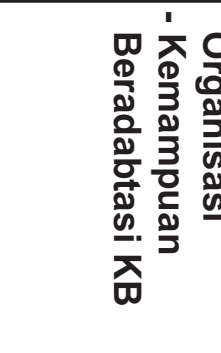 & 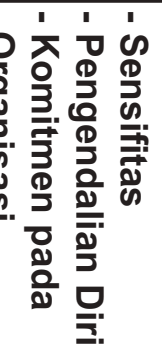 & 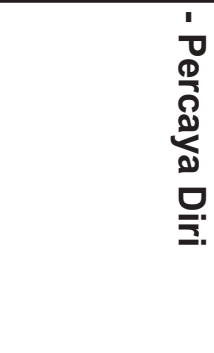 \\
\hline 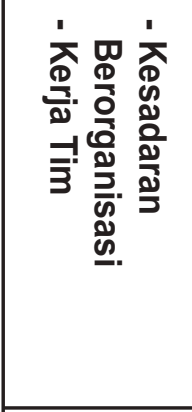 & 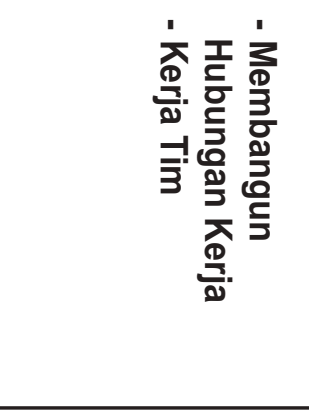 & 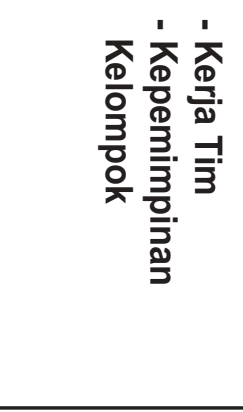 & & 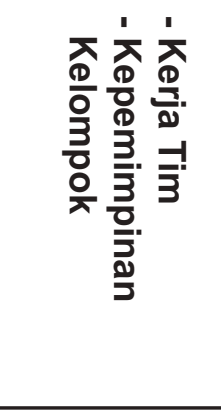 & 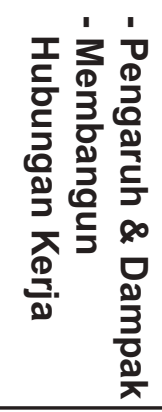 & 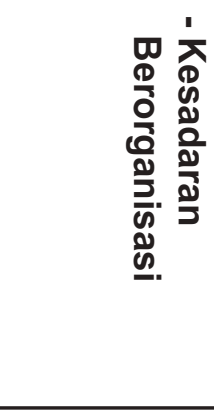 \\
\hline 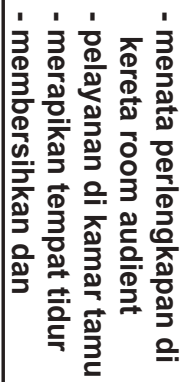 & 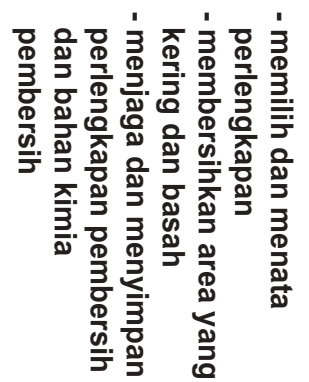 & 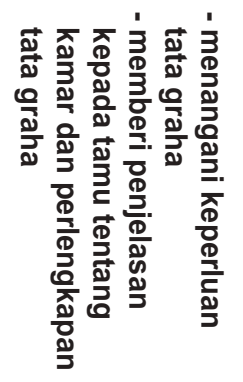 & 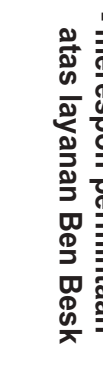 & 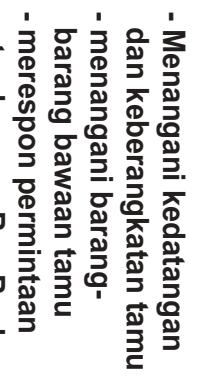 & 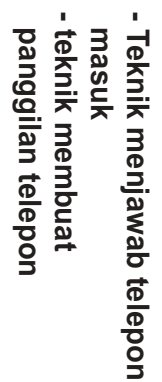 & 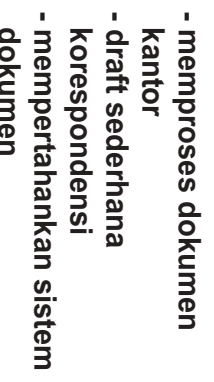 \\
\hline
\end{tabular}




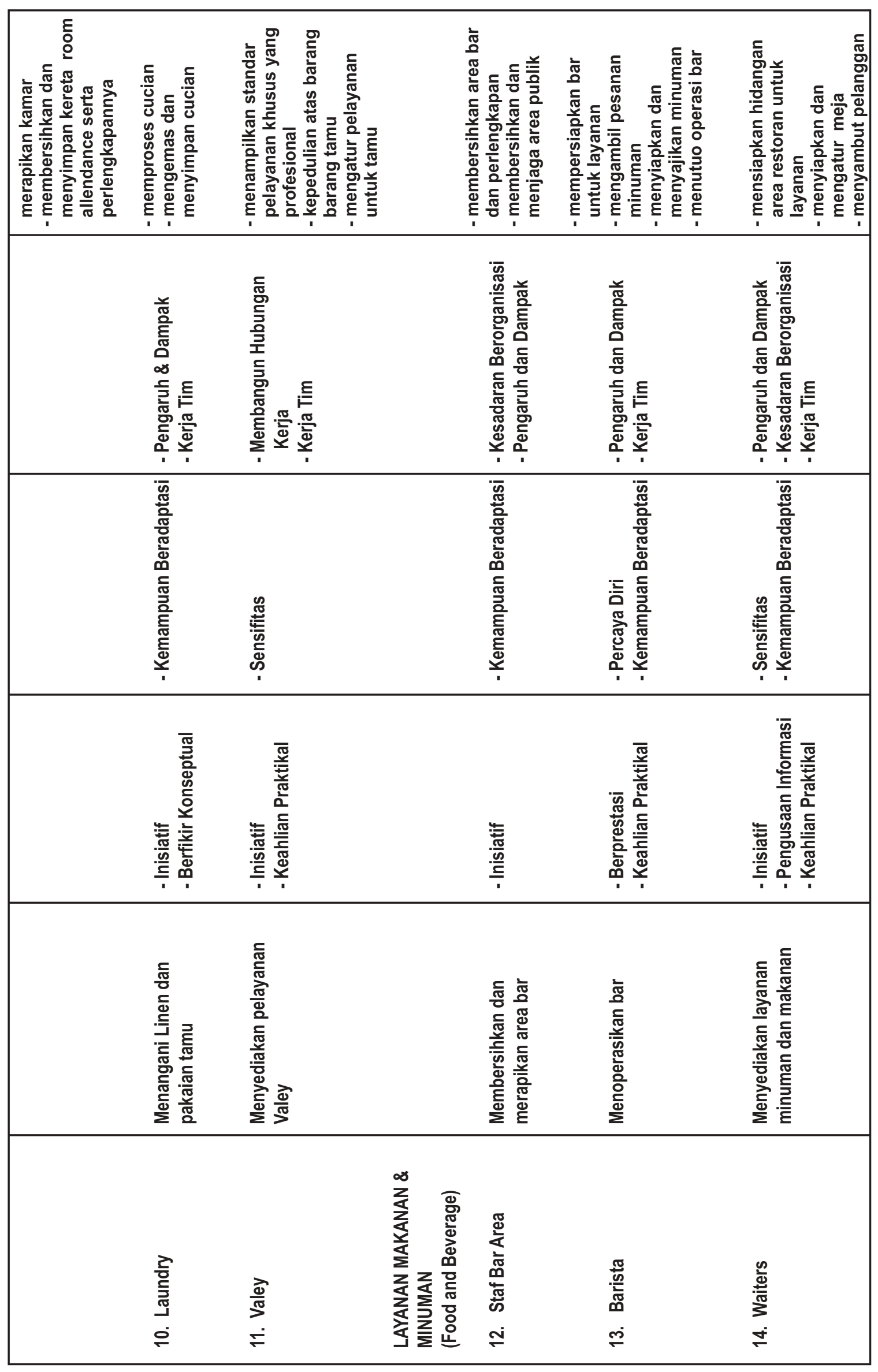




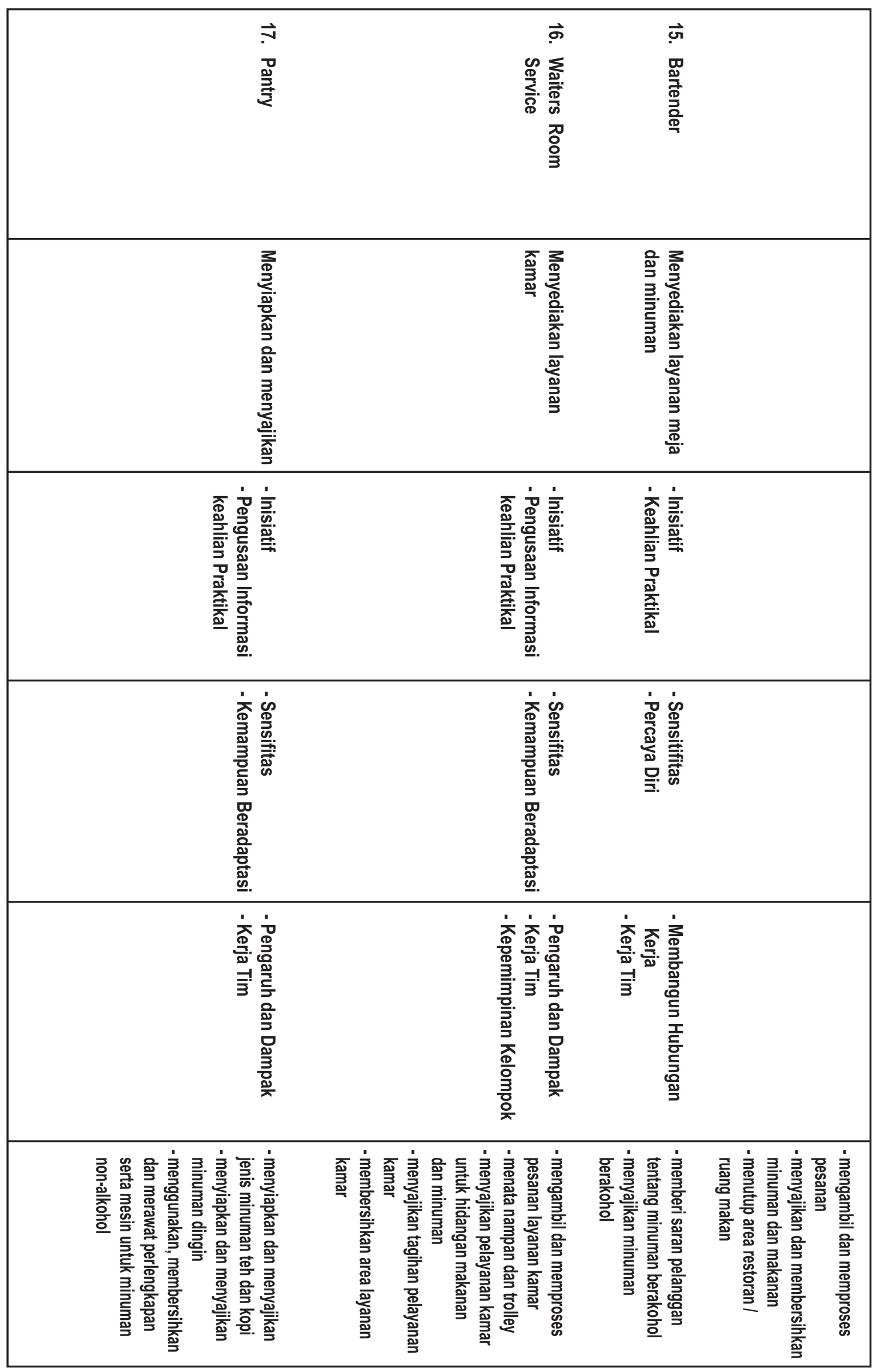




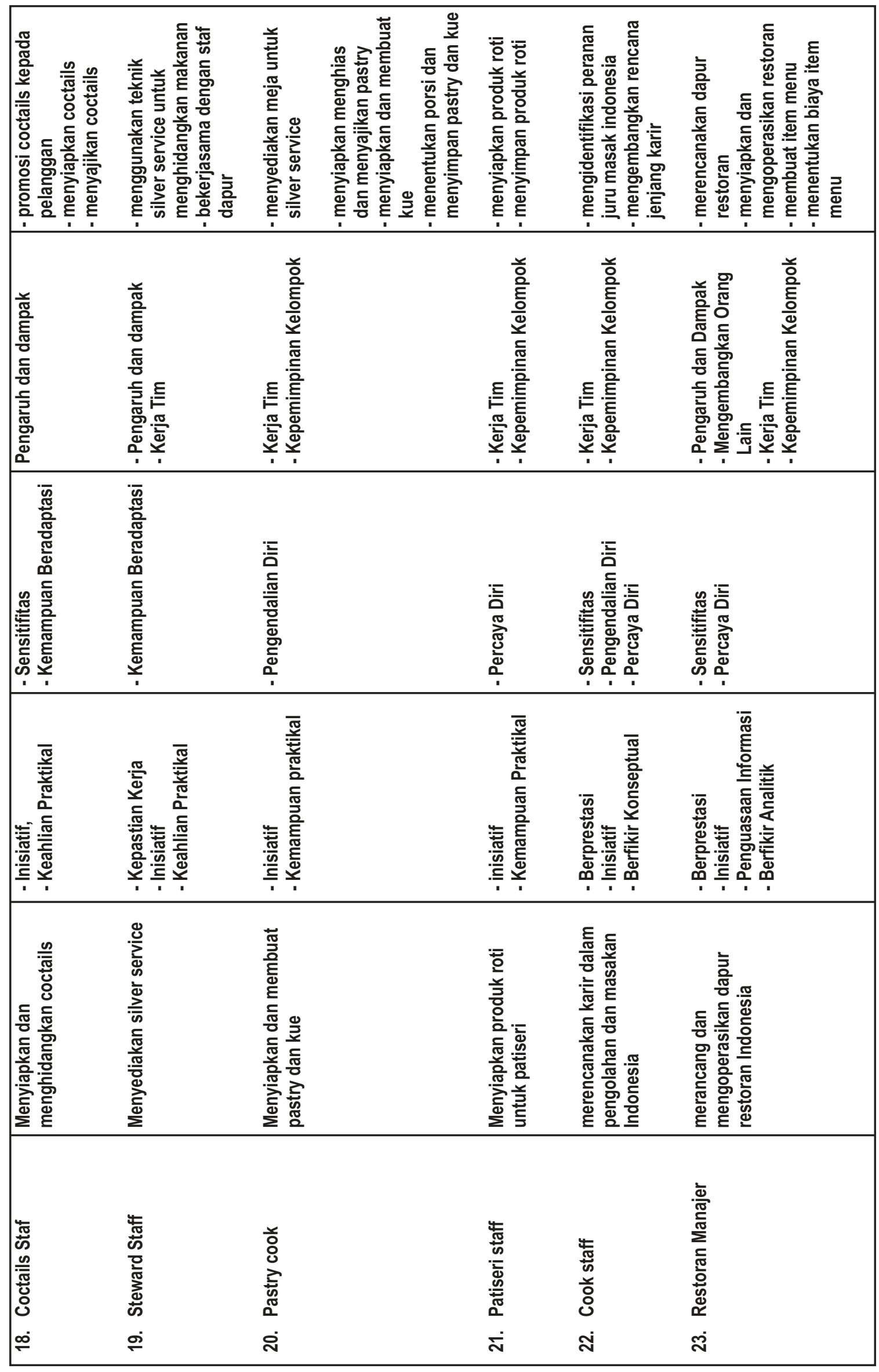


Strategi Pengembangan Kompetensi SDM Industri Perhotelan di Bantul

Industri perhotelan pada saat ini sudah sangat berkembang di Kabupaten Bantul. Industri perhotelan merupakan industri jasa usaha padat karya artinya dukungan Sumber Daya Manusia menjadi andalan kesuksesan bisnisnya. Upaya untuk meningkatkan kemampuan sumber daya manusia menjadi lebih profesional sudah menjadi kebutuhan peningkatan pelayanan pelanggan.

Pengembangan SDM perhotelan di kabupaten Bantul membutuhkan strategi khusus, hal demikian dilakukan karena dari 95 hotel yang terdaftar, dalam kenyataanya hampir sebagian besar hanyalah merupakan usaha penginapan atau losmen yang pengelolaannya sangat sederhana dan jauh dari ketentuan yang ada. Oleh karenanya model pengembangan SDM nyapun harus dibuatkan kelas kelas pengembangan yang bersifat umum dan bersifat khusus agar memberikan dampak pada pengelolaan yang lebih baik. Pengembangan Kompetensi SDM yang bersifat umum bisa diikuti oleh semua kelas sedangkan pengembangan kompetensi yang bersifat khusus tentunya akan lebih berdaya guna jika diikuti oleh SDM Perhotelan yang sudah memiliki organisasi yang matang.

Sebelum ditetapkan strtategi pengembangan kompetensi SDM perhotelan, terlebih dulu harus dikemukakan kelebihan dan kekurangan serta peluang dan tantangan dari SDM perhotelan di Kabupaten Bantul Kelebihan Tenaga Perhotelan di Bantul ( S )

1. Banyak penginapan yang mempekerjakan SDM walau mereka tidak memiliki kompetensi bidang hotel.

2. Jumlah penginapan termasuk yang tidak tercatat lebih dari duaratus limapuluh penginapan, pemilik tentu memerlukan peningkatan usahanya oleh karenanya memerlukan SDM yang memeiliki berkompetensi.

Kekurangan Tenaga Perhotelan di Bantul (W)

1. Motivasi dan keinginan maju dipengaruhi oleh kondisi tempat mereka bekerja

2. Inisiatif dan kemauan kerja kurang kuat

3. Standar kompetensi kerjanya ditentukan oleh pemilik hotel

4. Rata rata mereka yang bekerja di penginapan banyak yang lulusan Sekolah Menengah Pertama dan tertinggi hanyalah tingkat SMA.

Kesempatan dan Peluang $(\mathrm{O})$

1. Pemerintah serius berkeinginan membantu mengembangkan kompetensi SDM Perhotelan

2. Seiring dengan perkembangan pariwisata dengan ragam distinasinya maka akan bermunculan hotel hotel yang berstandar internasional yang artinya dimasa depan akan banyak dubutuhkan tenaga yang tentunya memiliki kompetensi bidang hotel.

Tantangan dan Ancaman ( T)

1. Banyak industri lain yang membutuhkan SDM dengan masa depan yang menjanjikan

2. Pengelolaan hotel akan dituntut semua SDMnya harus memiliki Sertifikat resmi dari BNSP

Strategi SO

Mendorong pengusaha sekaligus mengancam tidak akan memperpanjang ijin usahanya, jika para pegawainya belum memiliki serifikat kompetensi. Hal ini bisa dilakukan secara efektif karena kementerian pariwisata sudah mencanangkan tahun 2019 seluruh SDM pariwisata termasuk hotel dan restoran harus sudah memiliki sertifikat uji kompetensi.

Strategi ST

Hotel baru yang akan berdiri secara tidak langsung akan memaksa pemilik penginapan dan hotel yang ada saat ini untuk bersaing agar tetap bisa hidup, oleh karenanya ijin pendirian hotel baru harus disertai persyaratan SDM yang sudah memiliki sertifikat uji Kompetensi.

Strategi WO

Diupayakan untuk bisa difasilitasi agar uji kompetensi SDM perhotelan dengan biaya ditanggung pemerintah, dari kementerian pariwisata melalui Lembaga Sertifikasi Profesi sejak tahun 2010 selalu mengucurkan dana bantuan untuk uji kompetensi bidang pariwisata.

Strategi WT

Perusahaan diwajibkan memberikan insentif kepada tenaga kerjanya yang sudah memiliki sertifikat Uji Kompetensi, sehingga para pekerja lebih bersemangat untuk bisa mengikuti uji kompetensi, karena dampaknyapun akan kembali kepada pengusaha itu sendiri yaitu memiliki tenaga yang kompeten juga akan membuat usahanya menjadi lebih maju.

\section{KESIMPULAN DAN REKOMENDASI}

Kesimpulan

Di Kabupaten Bantul usaha akomodasi berkembang sangat pesat mengikuti perkembangan pariwisata. Jumlah hotel dan penginapan yang ada sudah mencapai 95 buah untuk semua kelas dengan jumlah kamar medium, namun jika didata semua termasuk penginapan yang berada di lokasi obyek yang hanya memiliki satu kamar, maka jumlahnya mencapai 261 buah dan mungkin saja akan terus berkembang dimasa yang akan datang sejalan dengan munculnya obyek obyek wisata baru.

Pemerintah Kabupaten Bantul mencoba merumuskan strategi pengembangannya dengan melakukan studi identifikasi kebutuhan tenaga bagi industri perhotelan terutamapada kebutuhan kompetensinya agar bisa memberikan ruang bagi tumbuh dan berkembangnya industri perhotelan di Kabupaten Bantul di masa depan.

Kompetensi pada umumnya diartikan sebagai 
kecakapan, keterampilan, kemampuan. Kata dasarnya kompeten, berarti cakap, mampu atau terampil. Pada konteks manajemen sumber daya manusia, istilah kompetensi mengacu kepada atribut/karakteristik seseorang yang membuatnya berhasil dalam pekerjaan. Banyak pihak sering menggunakan istilah kompetensi sebagai kemampuan seseorang untuk berkinerja (the ability to perform). Hal ini dikarenakan efektif tidaknya suatu hasil pekerjaan sangat dipengaruhi oleh keterampilan, pengetahuan, perilaku (sikap) dan kemampuan yang sesuai dengan tuntutan pekerjaan.

Kompetensi menyangkut kewenangan setiap individu untuk melakukan tugas atau mengambil keputusan sesuai dengan peranannya dalam organisasi yang relevan dengan keahlian, pengetahuan, dan kemampuan yang dimiliki.

Studi yang dilakukan ini telah berhasil mengidentifikasi kebutuhan kompetensi SDM bagi Industri Perhotelan di kabupaten Bantul Yogyakarta sebagai berikut:

Dari data lapangan yang terkumpul berupa respon kuisioner Spencer \& Spencer yang dibagikan kepada 30 responden kemudian dikaji dengan skala Linkert dengan menggunakan prosen kemudian dibuat rangking untuk menemukan kondisi kompetensi riil. Hasil prosen Linkert kemudian dihitung rata ratanya yang dibandingkan dengan skala tertinggi“ paling penting' yaitu 4 untuk menemukan gap atau kesenjangan kompetensi. Dari rangking nilai gap terkecil tersebut sampai nilai gap terbesar maka ditemukan besaran kesenjangan kompetensi. Kompetensi dimaksud dalam kesenjangan ini adalah soft kompetensi.

Ketiga kelompok soft kompetensi masih membutuhkan upaya yang lebih keras lagi untuk dapat meningkat kompetensinya. Kondisi demikian adalah sebagai berikut :

1. Dari kompetensi intelektual sebanyak 14 elemen hanya bernilai 'penting', sementara yang bernilai 'sangat penting' tidak terdapat sama sekali. Urutan penting menurut para pekerja atau pemilik adalah keahlian praktikal berturut turut penguasaan informasi, inisiatif, kemampuan naratif sampai dengan urutan paling bawah adalah berprestasi.

2. Dari 5 kompetensi Emosional juga tidak terdapat kompetensi yang bernilai 'sangat penting' tetapi seluruhnya hanya bernilai 'penting' saja. Urutan yang menjadi prioritas responden adalah Komitmen pada organisasi, sensitivitas, percaya diri kemampuan beradaptasi, dan pengendalian diri.

3. Dari kompetensi sosial yang berjumlah 8 elemen, juga diperoleh kompetensi bernilai 'penting' sedangkan yang bernilai 'sangat penting' juga tidak terdapat. Urutan prioritas menurut mereka adalah kepemimpinan kelompok, mengarahkan bawahan dan kerja tim.

4. Urutan prioritas kebutuhan peningkatan kompetensi SDM dimulai dari kompetensi yang memiliki nilai gap atau kesenjangan yang paling besar menuju gap yang paling kecil seperti yang tersaji dalam tabel 2 .

5. Kebutuhan kompetensi tenaga perhotelan tentunya akan menggabungkan antara hard kompetensi dengan soft kompetensi yang tersaji pada tabel 3

Rekomendasi

Pengembangan SDM perhotelan di kabupaten Bantul membutuhkan strategi khusus, hal demikian dilakukan karena dari 95 hotel yang terdaftar, dalam kenyataanya hampir sebagian besar hanyalah merupakan usaha penginapan atau losmen yang pengelolaannya sangat sederhana dan jauh dari ketentuan yang ada. Oleh karenanya model pengembangan SDM nyapun harus dibuatkan kelas kelas pengembangan yang bersifat umum dan bersifat khusus agar memberikan dampak pada pengelolaan yang lebih baik. Pengembangan Kompetensi SDM yang bersifat umum bisa diikuti oleh semua kelas sedangkan pengembangan kompetensi yang bersifat khusus tentunya akan lebih berdaya guna jika diikuti oleh SDM Perhotelan yang sudah memiliki organisasi yang matang.

Mendorong pengusaha sekaligus mengancam tidak akan memperpanjang ijin usahanya, jika para pegawainya belum memiliki serifikat kompetensi. Hal ini bisa dilakukan secara efektif karena kementerian pariwisata sudah mencanangkan tahun 2019 seluruh SDM pariwisata termasuk hotel dan restoran harus sudah memiliki sertifikat uji kompetensi.

Hotel baru yang akan berdiri secara tidak langsung akan memaksa pemilik penginapan dan hotel yang ada saat ini untuk bersaing agar tetap bisa hidup, oleh karenanya ijin pendirian hotel baru harus disertai persyaratan SDM yang sudah memiliki sertifikat uji Kompetensi.

Diupayakan untuk bisa difasilitasi agar uji kompetensi SDM perhotelan dengan biaya ditanggung pemerintah, dari kemeterian pariwisata melalui Lembaga Sertifikasi Profesi sejak tahun 2010 selalu mengucurkan dana bantuan untuk uji kompetensi bidang pariwisata.

Perusahaan diwajibkan memberikan insentif kepada tenaga kerjanya yang sudah memiliki sertifikat Uji Kompetensi, sehingga para pekerja lebih bersemangat untuk bisa mengikuti uji kompetensi.

\section{DAFTAR PUSTAKA}

Palan, R. 2007. Competency Management, Teknik Mengimplementasikan Manajemen SDM Berbasis Kompetensi Untuk Meningkatkan Daya Saing Organisasi, Cetakan Pertama, Edisi Bahasa Indonesia, Jakarta: PPM Anggota IKAP,

Pfeffer, J, Soetjipto Budi W, Handoko T. Hani, 2003. Paradigma Baru Manajemen Sumber Daya Manusia, 
Cetakan Keempat, Edisi Kedua, Yogyakarta: Amara Books,

Rivai, Veithzal. 2009. Manajemen Sumber Daya Manusia Untuk Perusahaan, Jakarta: PT. Raja Grafindo Persada,

Simamora, Henry. 2004. Manajemen Sumber Daya Manusia, Cetakan Pertama, Yogyakarta: STIE YKPN,

Spencer, M., Lyle, Jr, \& Signe M. Spencer, 1993 Competence at Work "Models for Superior Performance", New York: John Wiley \& Sons Inc,.

Sudarmanto, 2009. Kinerja dan Pengembangan Kompetensi SDM, Yogyakarta: Pustaka Belajar,

Tjutju, \& Suwatno, 2009. Manajemen Sumber Daya Manusia, Bandung: Alfabeta,

Wibowo. 2007. Manajemen Kinerja, Edisi Ketiga, Jakarta: Rajawali Press, 